\title{
APPROVAL-SYSTEM PROPOSAL SKRIPSI MAHASISWA PADA PROGRAM STUDI S-1 SISTEM INFORMASI DI UNIVERSITAS NUSANTARA PGRI KEDIRI
}

\author{
Aidina Ristyawan \\ Fakultas Teknik, Program Studi Sistem Informasi \\ Universitas Nusantara PGRI Kediri \\ Email: aidinaristi@unpkediri.ac.id
}

\begin{abstract}
ABSTRAK
Untuk menyetujui judul penelitian yang diajukan mahasiswa oleh dosen pembimbing membutuhkan cara yang cukup rumit guna menghasilkan kualitas penelitan yang baik dan sebaran bidang ilmu yang merata. Salah satu cara yang dapat digunakan untuk membantu persetujuan judul penelitian tersebut adalah dengan menggunakan sistem pembobotan judul penelitian yang diusulkan mahasiswa. Dengan sistem pembobotan judul penelitian tersebut dosen pembimbing dapat terbantu dalam menyetujui judul penelitian yang diajukan oleh mahasiswa bimbingannya, sehingga kualitas penelitian semakin meningkat dan sebaran bidang ilmu penelitian juga lebih merata. Sistem pembobotan judul penelitian ini menggunakan kombinasi logika fuzzy (samar) dan pembuatan keputusan berdasar beberapa atribut (Multi Atribut Decission Making / MADM). Penentuan bobot judul penelitian berdasarkan pada beberapa aspek, yaitu 1) Kriteria, dimana kriteria penentuan bobot bisa diisi atau disesuaikan dengan program studi lain; 2) Bobot, yang mana digunakan segai pembobotan atau prioritas masing - masing kriteria; 3) Jenis kriteria yang terbagi menjadi menjadi dua (kriteria keuntungan dan kriteria biaya); dan 4) Batas bobot minimum lolos. Hasil dari pembobotan judul penelitian ini berupa angka bobot antara 0 sampai dengan 1 , yang dapat diketahui lolos tidaknya judul penelitian yang diajukan sesuai dengan batas bobot minimum lolos.
\end{abstract}

Kata kunci: pembobotan; logika fuzzy; MADM.

\section{ABSTRACT}

To approve the title of research proposed by the student by the supervisor requires a fairly complicated way to produce good quality research and distribution of equitable field of knowledge. One way that can be used to help approval of the title of the research is to use a weighted system of research titles proposed by the student. With the weighting system of the title of the research supervisor lecturers can be helpful in approving the title of research submitted by the students guidance, so that the quality of research is increasing and the distribution of research fields are also more evenly distributed. The title system of this research uses a combination of fuzzy logic and decision making based on several attributes (Multi Attribute Decision Making / MADM). Determination of the weight of research titles based on several aspects, namely 1) Criteria, where the weight determination criteria can be filled or adjusted with other study programs; 2) Weights, which are used in terms of weighting or priority of each criterion; 3) Types of criteria divided into two (profit criteria and cost criteria); and 4) The minimum weight limit passes. The result of the weighting of the title of this research is a weighted number of 0 to 1 , which can be known to pass the title of the research submitted in accordance with the minimum weight limit passed.

Keywords: weighting; fuzzy logic; MADM..

\section{PENDAHULUAN}

Kualitas penelitan yang baik dan sebaran bidang ilmu yang merata merupakan salah satu bukti kemajuan suatu perguruan tinggi. Skripsi merupakan salah satu penelitian akhir yang dikerjakan oleh mahasiswa. Pembuatan penelitian tersebut pasti didampingi oleh dosen pembimbing yang diawali dengan pengajuan judul dan, yang mana salah satu tugas dosen pembimbing adalah menyetujui pengajuan judul tersebut berdasar kriteria tertentu. Untuk membantu memutuskan apakah suatu judul yang diajukan disetujui atau tidak bisa dilakukan dengan menggunakan pembobotan judul penelitian.

Sistem pembobotan judul penelitian ini menggunakan kombinasi logika fuzzy (samar) dan pembuatan keputusan berdasar beberapa atribut (Multi Atribut Decission Making / MADM). Penentuan bobot judul penelitian berdasarkan pada beberapa aspek, yaitu 1) Kriteria, dimana kriteria penentuan bobot bisa diisi atau disesuaikan dengan program studi lain; 2) Bobot, yang mana digunakan segai pembobotan atau prioritas masing - masing kriteria; 3) Jenis kriteria yang terbagi menjadi menjadi dua (kriteria keuntungan dan kriteria biaya); dan 4) Batas bobot minimum lolos. 
Bobot penelitian yang didapat dari judul proposal masih bersifat samar [1]. Hal ini dikarenakan terdapatnya perbedaan kedalaman keilmuan, tingkat pemahaman dan tingkat rasionalitas pemikiran baik mahasiswa maupun dosen pembimbing. Dalam hal ini suatu logika Fuzzy dapat digunakan untuk merepresentasikan bobot tersebut karena logika Fuzzy dapat menyatakan sesuatu ke dalam sebagaian himpunan dan ke dalam sebagian himpunan lain pada waktu yang sama yang dinyatakan dengan angka antara 0 dan 1 [2]. Salah satu penggunaan Logika Fuzzy dalam pengambilan keputusan adalah metode Fuzzy Multi Attribute Decision Making (FMADM). FMADM merupakan metode pengambilan keputusan berdasarkan beberapa kriteria tertentu.

Hasil dari pembobotan judul penelitian ini nantinya berupa angka bobot antara 0 sampai dengan 1, yang dapat diketahui lolos tidaknya judul penelitian yang diajukan sesuai dengan batas bobot minimum lolos.

Penelitian yang menginspirasi dibuatnya judul ini adalah Penggunaan kombinasi Fuzzy Tsukamoto dan Algoritma SAW [1]. Penelitian yang akan dilakukan mengambil judul dan pemahaman mahasiswa mengenai penelitian yang akan dikerjakan berdasar judul yang diajukan, tujuan penelitian ini membantu dosen menentukan suatu judul disetujui atau tidak.

Berdasar latar belakang tersebut beberapa rumusan masalah yaitu : 1) Bagaimana membuat approval system proposal skripsi mahasiswa ? 2) Bagaimana menerapkan kombinasi algoritma Fuzzy Tsukamoto dan SAW pada sistem pembobotan judul penelitian mahasiswa ? Sehingga pada penelitian ini bertujuan untuk 1) Membuat approval system proposal skripsi mahasiswa, 2) Menerapkan kombinasi algoritma Fuzzy Tsukamoto dan SAW pada sistem pembobotan judul penelitian mahasiswa, 3) Hingga nantinya membantu dosen pembimbing proposal Program Studi Sistem Informasi Universitas Nusantara PGRI Kediri untuk menjaring atau menyeleksi judul yang diajukan mahasiswa.

\subsection{Sistem Penunjang Keputusan}

Menurut Bonczek, dkk., dalam buku Decision Support System And Intelligent system [3] mengatakan bahwa sistem pendukung keputusan adalah suatu sistem komputer yang di dalamnya terdapat tiga komponen yang saling berinteraksi. Komponen tersebut adalah :

a) Sistem bahasa (menangani komunikasi antara pengguna dengan komponen sistem pendukung keputusan lain).

b) Sistem pengetahuan (basis pengetahuan yang ada pada sistem pendukung keputusan atau sebagai data atau sebagai prosedur)

c) Sistem pemrosesan masalah (yang menghubungkan antara sistem Bahasa dan sistem pengtahuan, serta memiliki kemampuan untuk memanipulasi masalah umum yang diperlukan untuk pengambilan keputusan).

Sistem pendukung keputusan memiliki beberapa karakteristik, diantaranya adalah :

a) sebagai penunjang atau alat bantu dalam pengambilan keputusan suatu organisasi atau perusahaan.

b) Terdapat antarmuka dimana manusia (user) tetap memegang kontrol proses pengambilan keputusan.

c) Mendukung pengambilan keputusan untuk menyelsaikan masalah baik terstruktur atau semi terstruktur serta mendukung beberapa keputusan yang saling berkaitan.

d) Memiliki kapasitas dialog untuk memperoleh informasi sesuai dengan kebutuhan.

e) Terdapat subsistem yang terintegrasi sedimikian rupa sehingga dapat berfungsi sebagai satu kesatuan sistem.

f) Terdapat dua komponen utama : data dan model.

\subsection{Algoritma Fuzzy Tsukamoto}

Pada Metode Tsukamoto [4], setiap konsekuen pada aturan yang berbentuk IF-Then harus direpresentasikan dengan suatu himpunan fuzzy dengan fungsi keanggotaan yang monoton. Sebagai hasilnya, output hasil inferensi dari tiap-tiap aturan diberikan secara tegas (crisp) berdasarkan $\alpha$ - predikat (fire strength). Hasil akhirnya diperoleh dengan menggunakan rata-rata terbobot [5] Berikut gambar inferensi dengan menggunakan Metode Tsukamoto pada gambar 1. 


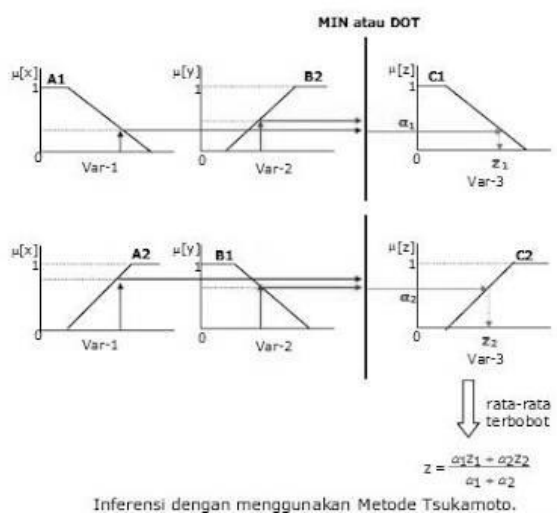

Gambar 1. Fungsi Keanggotaan Linear Naik

\subsection{Fuzzy}

Fuzzy dapat diartikan sebagai kabur atau samar, dalam fuzzy terdapat derajat keanggotaan yang memiliki rentang nilai 0 sampai 1 . Berbeda dengan himpunan yang memiliki nilai 0 dan 1 , sedangkan logika fuzzy suatu cara yang tepat untuk memetakan suatu ruang input kedalam suatu ruang output, mempunyai nilai kontinyu. Fuzzy dinyatakan dalam derajat dari suatu keanggotaan dan derajat dari kebenaran. Oleh sebab itu menurut Kusumadewi: sesuatu dapat dikatakan sebagian benar dan sebagian salah pada waktu yang sama [7][6].

\subsection{Algoritma Simple Additive Weighting (SAW)}

Metode simple additive weighting (SAW) merupakan metode penjumlahan terbobot. Konsep dasar metode simple additive weighting (SAW) adalah mencari penjumlahan terbobot dari rating kinerja pada setiap alternatif pada semua kriteria. Metode ini membutuhkan proses normalisasi matrik keputusan (X) ke suatu skala yang dapat diperbandingkan dengan semua rating alternatif yang ada, Berikut adalah persamaan yang ada dalam metode SAW [7][6].

$$
r_{i j}=\left\{\begin{array}{l}
\frac{x_{i j}}{\operatorname{Max}_{i j}\left(x_{i j}\right)} \text { Jika jadalah kriteria keuntungan (benefit) } \\
\frac{\operatorname{Min}_{i j}\left(x_{i j}\right)}{x_{i j}} \quad \text { Jika jadalah kriteria biaya (cost) }
\end{array}\right.
$$

Keterangan :

$\mathrm{Rij} \quad=$ nilai rating kinerja normalisasi

$\mathrm{Xij}=$ nilai atribut yang dimiliki dari setiap kriteria

$\operatorname{Max}(x i j) \quad=$ nilai terbesar dari setiap kriteria

$\operatorname{Min}(x i j) \quad=$ nilai terkecil dari setiap kriteria

Benefit = nilai terbesar adalah terbaik

Cost $=$ nilai terkecil adalah terbaik

alternatif Ai pada atribut $\mathrm{Cj} ; \mathrm{i}=1,2, \ldots, \mathrm{m}$ dan $\mathrm{j}=1,2, \ldots, \mathrm{n}$. Nilai preferensi untuk setiap alternative (Vi) diberikan sebagai:

$$
V_{i}=\sum_{j=1}^{n} W_{j} r_{i j}
$$

Keterangan :

$\mathrm{Vi}=$ ranking untuk setiap alternatif

$\mathrm{wj}=$ nilai bobot dari setiap kriteria

rij = nilai rating kinerja ternormalisasi

Nilai $V_{i}$ yang lebih besar mengindikasikan bahwa alternatif $A_{i}$ merupakan alternatif terbaik. 


\subsection{Database MySQL}

Menurut Kadir [7], istilah database memiliki arti sebagai berikut: Database merupakan kumpulan data yang saling terkait. Secara praktis, basis data dapat diartikan sebagai susunan data yang terstruktur dan disimpan dalam media penyimpan (hard disk) yang bertujuan agar data tersebut dapat diakses dengan mudah dan cepat.

Menurut Kadir [7] MySQL data diartikan sebagai berikut: MySQL adakah perangkat lunak DBMS ( Database Management System ) yang bersifat Open Source. Open Source yang dimaksud di sini adalah perangkat lunak tersebut dilengkapi dengan source code (kode Bahasa pemrograman yang digunakan untuk membuat MySQL).

Database Management System (DBMS) adalah kumpulan program yang digunakan untuk mendefinisikan, mengatur dan memproses database. DBMS merupakan alat yang berperan untuk membangun struktur tersebut.

MySQL awalnya dibuat oleh perusahaan konsultan bernama TcX yang berlokasi di Swedia. Saat ini pengembangan MySQL berada dibawah naungan perusahaan MySQL AB. Adapun perangkat lunak ini dapat diunduh di situs www.mysql.com.

Sebagai perangkat lunak DBMS, MySQL dilengkapi dengan beberapa fitur sebagai berikut :

a. Multiplatform

MySQL tersedia untuk beberapa platform system operasi (Windows, Linux, Unix, dan lain-lain).

b. Handal, cepat, dan mudah digunakan

MySQL digunakan sebagai server database (server yang melayani permintaan terhadap database) yang handal, dapat menangani lingkup database yang besar dengan kecepatan tinggi, mendukung fungsi untuk mengakses database, dan memberikan kemudahan untuk digunakan.

c. Jaminan keamanan akses

MySQL memiliki pengamanan database dengan menggunakan hak akses atau previlleges. Misal, kemampuan mengatur hak akses suatu pengguna tertentu agar dapat mengakses data yang bersifat rahasia ( misalnya gaji pegawai ), sedangkan pengguna lain tidak boleh.

d. Dukungan SQL

Seperti tersirat dalam namanya, MySQL mendukung perintah SQL (Structured Query Language). Sebagaimana diketahu MySQL, merupakan standar dalam pengaksesan database relasional. Pengetahuan akan SQL akan memudahkan siapapun untuk menggunakan MySQL.

\section{METODOLOGI PENELITIAN}

Metode penelitian dapat diartikan sebagai cara ilmiah untuk mendapatkan data dengan tujuan dan kegunaan tertentu [8]. Metode penelitian yang digunakan pada penelitian ini adalah metode Research and Development. Hal ini sesuai dengan tujuan untuk mengembangkan sistem pembobotan judul penelitian mahasiswa yang dapat membantu dosen pembimbing dalam menjaring atau menyeleksi judul yang diajukan mahasiswa.

\subsection{Jenis Pengembangan Perangkat Lunak}

Adapun langkah - langkah yang dilakukan peneliti adalah pengembangan perangkat lunak aplikasi menggunakan Metode air terjun (Waterfall).

\subsection{Metode Pengumpulan data}

Agar pembuatan sistem yang dilakukan pada penelitian ini lebih terarah dan terstruktur, maka pengumpulan data yang dilakukan pada penelitian ini terdiri dari :

a. Studi kepustakaan

Peneliti melakukan studi kepustakaan dengan cara mencari informasi melalui jurnal, buku dan prosiding yang telah ada sebelumnya, yang sesuai dengan bidang penelitian ini. Berdasar dari sumber - sumber pustaka tersebut peneliti berharap, hasil dari penelitian ini lebih bermanfaat dan mengandung unsur kebaruan penelitian.

b. Wawancara

Pengumpulan data melalui wawancara pada penelitian ini dilakukan kepada dosen dan ketua program studi objek penelitian guna memperoleh dan memastikan kebenaran informasi yang didapat. 
c. Observasi / Pengamatan

Data yang didapatkan dari pengamatan langsung proses pemilihan judul proposal penelitian pada objek penelitian.

d. Dokumentasi

Dokumentasi yang dilakukan pada penelitian ini diambil dari berkas proposal yang ada pada objek penelitian.

\subsection{Analisa Perhitungan Pemobobotan}

Analisa perhitungan pembobotan yang dilakukan pada penelitian ini adalah kombinasi penggunaan algoritma SAW dan Fuzzy Tsukamoto, dimana algoritma Fuzzy Tsukamoto digunakan untuk menentukan bobot nilai pada masing masing kriteria [1]. Dari penelitian tersebut menunjukkan bahwa penggunakan algoritma Fuzzy Tsukamoto pada proses pembobotan dapat memberikan bobot nilai yang lebih presisi berdasar keadaan data sebenarnya.

Pada penelitian ini dibutuhkan beberapa variabel untuk membantu proses perhitungan. Adapun beberapa variabel tersebut adalah :

1) kriteria pembobotan, dimana kriteria pembobotan terdiri atas :

a.Frekuensi penggunaan algoritma yang sama pada penelitian sebelumnya

b.Bidang penelitian yang sama pada penelitian sebelumnya

c.Jumlah kombinasi algoritma yang digunakan

d.Kedalaman langkah penelitian

e.Jumlah penelitian sebelumnya yang sama

2) Jenis Kriteria, adapun jenis kriteria yang dibutuhkan adalah:

a. Benefit / Keuntungan

b. Cost / Biaya

3) Alternatif, adapun alternatif adalah data mahasiswa yang mengajukan judul.

4) Batas bawah preferensi / rangking, dimana batas bawah preferensi adalah nilai minimal preferensi / rangking yang disetujui oleh dosen. Pada penelitian ini ditetapkan sebesar 0,6.

\subsection{Analisa Kebutuhan}

Tujuan analisa kebutuhan adalah untuk mendapatkan spesifikasi kebutuhan pengguna. Adapun kebutuhan fungsional pada sistem pembobotan judul penelitian adalah :

1) Sistem dapat digunakan untuk mendata pengajuan judul penelitian mahasiswa.

2) Sistem dapat digunakan untuk mendata kriteria pembobotan.

3) Sistem dapat digunakan untuk pengaturan pembobotan kriteria pembobotan.

4) Sistem yang dihasilkan mampu pembobotan judul penelitan.

5) Sistem mampu menerapkan kombinasi algoritma Fuzzy Tsukamoto dan SAW untuk pembobotan judul penelitian mahasiswa

\subsection{Diagram Use Case}

Use case berfungsi untuk menggambarkan fungsionalitas yang diharapkan dari sebuah sistem. Diagram use case menyajikan interaksi antara use case dan aktor dalam sistem yang akan dikembangkan. Use case adalah fungsi-fungsi atau fitur-fitur apa saja yang disediakan oleh sistem informasi yang akan dikembangkan tersebut kepada pengguna sistem. Bisa juga meliputi fitur apa yang pengguna akan dapat lakukan terhadap sistem. Sedangkan aktor bisa berupa orang, peralatan, atau sistem lain yang berinteraksi terhadap sistem yang akan dibangun. [9]. Adapun use case pada penelitian ini terdapat pada gambar 2 . 


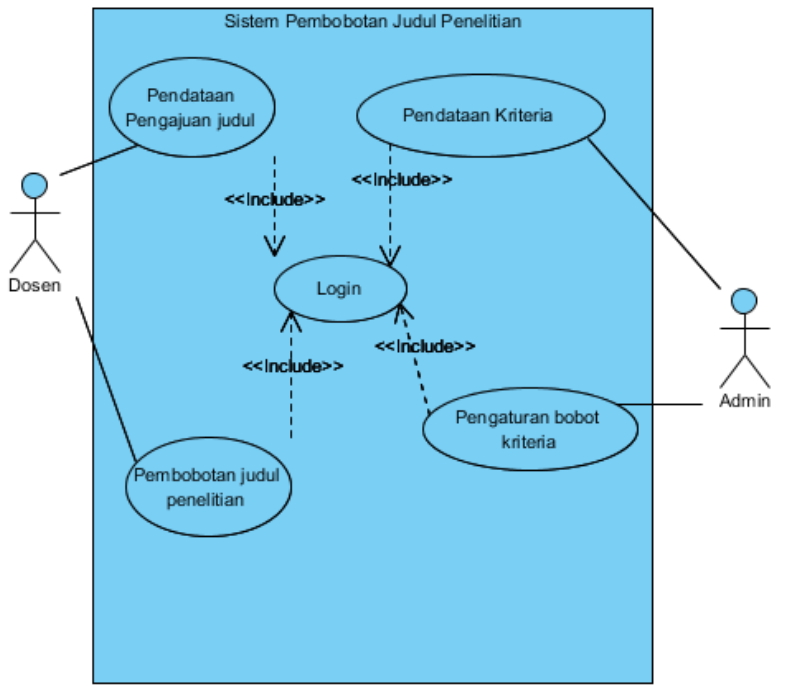

Gambar 2. Use Case Approval System Proposal Skripsi Mahasiswa

Pada diagram use case gambar 2 tersebut terdapat lima case atau bisa disebut dengan proses utama yang dubutuhkan dan dua actor atau selaku pengguna yang terdiri dari dua macam jenis pengguna (Admin dan pegawai). Penjelasan dari diagram use case tersebut adalah sebagai berikut :

1) Dosen selaku pembimbing menangani dua proses utama yaitu pendataan pengajuan judul dan pembobotan judul penelitian, dimana untuk melakukan dua proses tersebut dosen selaku pembimbing diharuskan melakukan login untuk masuk ke dalam sistem terlebih dahulu.

2) Hal - hal yang dikerjakan dalam proses pendataan pengajuan tersebut adalah manajemen data pengajuan judul yang diajukan oleh mahasiswa, manajemen data tersebut terdiri atas penambahan, perubahan dan bahkan penghapusan data pengajuan judul.

3) Hal - hal yang dikerjakan dalam proses pembobotan judul penelitian adalah menghitung atau menentukan bobot masing - masing judul yang diajukan oleh mahasiswa. Bila bobot judul tersebut sudah didapatkan maka dapat digunakan untuk membantu memutuskan apakah judul tersebut layak untuk dijadikan penelitan skripsi atau tidak dengan cara dibandingkan dengan bobot minimal yang telah disepakati dengan dosen program studi.

4) Untuk melakukan proses pembobotan judul penelitian yang dilakukan oleh dosen, pasti dibutuhkan kriteria sekaligus nilai atau tingkat bobot dari kriteria tersebut. Kriteria beserta bobot kriteria tersebut dikerjakan oleh admin yang terdapat pada case pendataan kriteria dan pengaturan bobot kriteria, yang mana untuk mengerjakan dua proses tersebut juga memerlukan proses login.

5) Hal - hal yang dikerjakan pada proses pendataan kriteria meliputi penambahan, perubahan dan penghapusan data kriteria.

6) Sedangkan untuk menentukan seberapa besar bobot nilai setiap kriteria dilakukan pada proses pengaturan bobot kriteria.

\subsection{Relasi Tabel}

Untuk membangun Approval-System Proposal Skripsi tersebut dibutuhkan perangkat lunak yang dapat digunakan untuk memanajemen data dari sistem, untuk itulah dibutuhkan suatu database untuk merancang relasi tabel. Pada gambar relasi tabel ini menggambarkan desain tabel dan hubungan masisng - masing tabel yang dibutuhkan untuk membuat sistem approval system proposal skripsi mahasiswa. Adapun relasi tabel yang digunakan ditunjukkan pada gambar 3. 


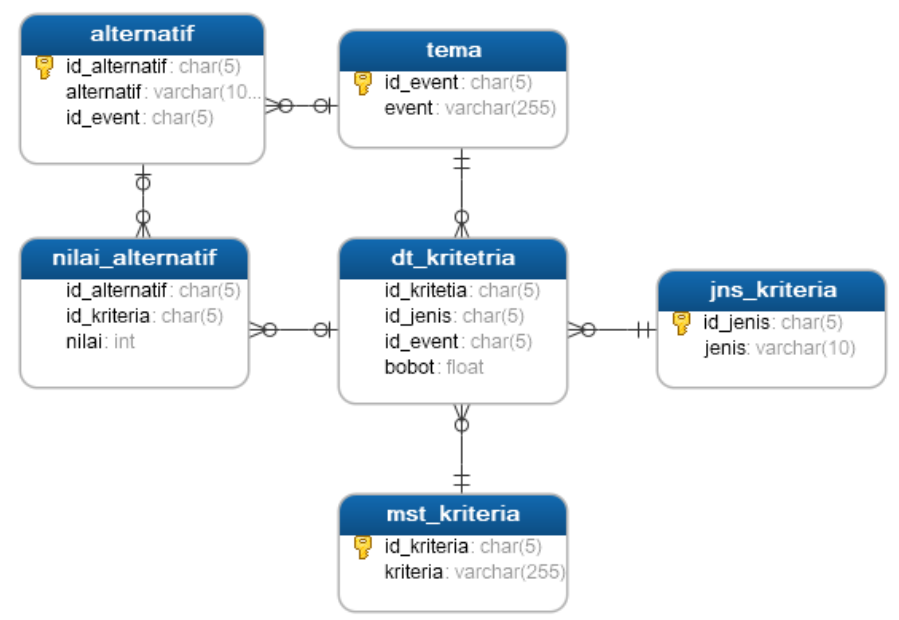

Gambar 3. Relasi Tabel

Pada sistem approval system proposal skripsi mahasiswa ini dibutuhkan enam tabel utama, diantaranya :

1) Tabel jns_kriteria, tabel ini digunakan untuk menyimpan jenis - jenis kiteria yang dibutuhkan dalam proses pembobotan judul. Jenis kriteria yang digunakan adalah kriteria Benefit sebagai kriteria yang bersifat nilai terbesar adalah nilai terbaik dan kriteria Cost sebagai kriteria yang nilai terkecilnya sebagai nilai terbaik. Pada tabel ini terdapat 2 field atau kolom, yaitu id_jenis yang berguna sebagai kunci utama / primary key dengan tipe data char kapasitas 5 karakter dan field jenis yang berguna untuk menampung karakter dari jenis kriteria dengan tipe data varchar kapasitas 10 karakter

2) Tabel mst_kriteria, tabel ini digunakan untuk menyimpan data - data kriteria yang digunakan dalam sistem, pada tabel ini menggunakan 2 field, yaitu id_kriteria sebagai kunci utama / primary key dengan tipe data char kapasitas 5 karakter dan field kriteria untuk menampung data kriteria dengan tipe varchar kapasitas 255 karakter.

3) Tabel tema, pada tabel ini digunakan untuk menyimpan data - data manajemen pengajuan judul tiap semesternya, sehingga sistem mampu memilah - milah alternatif mana saja yang akan dilakukan pembobotan berdasar periode pengajuannya. Pada tabel ini terdiri dari dua field, yaitu : id_event sebagai kunci utama / primary key dengan tipe data char kapasitas 5 karakter dan field event untuk menampung data periode pengajuan dengan tipe varchar kapasistas 255 karakter.

4) Tabel dt_kriteria, pada tabel ini berguna untuk menyimpan rincian detail beserta bobot dari kriteria yang tersimpan pada tabel mst_kriteria, pada tabel dt_kriteria ini mereferensi beberapa field primary key dari tabel mst_kriteria, jns_kriteria dan tema sebagai foreign key. Sehingga pada tabel ini menyimpan kriteria dengan jenis kriteria dan periode tertentu memiliki bobot. Kemudian pada tabel ini ditambahkan field bobot dengan tipe data float yang berguna untuk menyimpan nilai bobot dengan angka desimal.

5) Tabel alternatif, pada tabel digunakan untuk menyimpan data alternatif. Data alternatif yang dimaksud di sini adalah data judul yang diajukan oleh mahasiswa. Dan pada tabel ini data alternatif juga mengacu pada periode tertentu pada tabel event. Pada tabel ini membutuhkan tiga field, yaitu : id_alternatif yang berfungsi sebagai kunci utama / primary key dengan tipe data char kapasitas 5 karakter, field alternatif yang berfungsi untuk menyimpan data judul dengan tipa varchar berkapasitas 100 karakter dan id_event yang merefernsi pada tabel event.

6) Tabel nilai_alternatif : yang berfungsi untuk menyimpan nilai setiap kriteria (dengan merefernsi pada tabel dt_kriteria) dari masing masing alternatif (dengan mereferensi dari tabel alternatif). Kemudian ditambahkan pula field nilai dengan tipe integer untuk menyimpan nilai dengan bilangan bulat. 


\section{HASIL DAN PEMBAHASAN}

\subsection{Implementasi Kombinasi Algoritma SAW-Fuzzy Tsukamoto}

Pada penelitian ini untuk melakukan implementasi perhitungan pembobotan judul penelitian dibutuhkan beberapa kriteria dan bobot masing - masing kriteria, diantaranya terdapat pada tabel 1 sebagai berikut :

Tabel 1. Kriteria dan bobot

\begin{tabular}{lll}
\hline Kriteria & Keterangan & Bobot \\
\hline C1 & Frekuensi penggunaan algoritma yang sama pada penelitian & 0,15 \\
C2 & sebelumnya & 0,05 \\
C3 & Bidang penelitian yang sama pada penelitian sebelumnya & 0.35 \\
C4 & Kumlah kombinasi algoritma yang digunakan & 0.40 \\
C5 & Jumlah penelitian sebelumnya yang sama & 0.05 \\
\hline
\end{tabular}

Dengan menggunakan formula (1), maka kriteria seperti yang tersebut pada tabel 1 dapat digolongkan menjadi 2 jenis kriteria, yaitu kriteria keuntungan (benefit) dan kriteria biaya (cost). Adapun hasil penggolongan kriteria tercantum pada tabel 2.

Tabel 2. Jenis Kriteria

\begin{tabular}{lll}
\hline Kriteria & Jenis Kriteria & Kode \\
\hline C1 & Biaya (cost) & $\mathrm{C}$ \\
C2 & Biaya (cost) & $\mathrm{C}$ \\
C3 & Keuntungan (benefit) & $\mathrm{B}$ \\
C4 & Keuntungan (benefit) & $\mathrm{B}$ \\
C5 & Biaya (cost) & $\mathrm{C}$ \\
\hline
\end{tabular}

Adapun data nilai masing - masing kriteria setiap mahasiswa yang didapatkan oleh peneliti tercantum pada Tabel 3.

Tabel 3. Nilai masing - masing kriteria mahasiswa

\begin{tabular}{cccccc}
\hline Mhs & $\boldsymbol{C 1}$ & $\boldsymbol{C 2}$ & $\boldsymbol{C 3}$ & $\boldsymbol{C 4}$ & $\boldsymbol{C 5}$ \\
\hline 1. & 6 & 3 & 0 & 1 & 7 \\
2. & 6 & 1 & 3 & 0 & 1 \\
3. & 10 & 4 & 1 & 2 & 9 \\
4. & 8 & 6 & 4 & 0 & 5 \\
5. & 3 & 5 & 1 & 0 & 0 \\
6. & 8 & 8 & 1 & 0 & 9 \\
7. & 8 & 3 & 1 & 2 & 2 \\
\hline
\end{tabular}

Langkah berikutnya adalah pemberian bobot nilai pada masing masing kriteria dengan menggunakan algoritma Fuzzy Tsukamoto, ditentukan dengan menghitung nilai keanggotaan pada setiap kriteria yang tercantum pada tabel 4.

Tabel 4. Nilai keanggotaan pada setiap kriteria

\begin{tabular}{cccccccccc}
\hline C1 Rendah & \multirow{2}{*}{ C1 Tinggi } & $\begin{array}{c}\text { C2 } \\
\text { Rendah }\end{array}$ & $\begin{array}{c}\text { C2 } \\
\text { Tinggi }\end{array}$ & $\begin{array}{c}\text { C3 } \\
\text { Rendah }\end{array}$ & $\begin{array}{c}\text { C3 } \\
\text { Tinggi }\end{array}$ & $\begin{array}{c}\text { C4 } \\
\text { Rendah }\end{array}$ & $\begin{array}{c}\text { C4 } \\
\text { Tinggi }\end{array}$ & $\begin{array}{c}\text { C5 } \\
\text { Rendah }\end{array}$ & $\begin{array}{c}\text { C5 } \\
\text { Tinggi }\end{array}$ \\
\hline 0.57142857 & 0.42857143 & 0.714286 & 0.285714 & 1 & 0 & 0.5 & 0.5 & 0.222222 & 0.777778 \\
0.57142857 & 0.42857143 & 1 & 0 & 0.25 & 0.75 & 1 & 0 & 0.888889 & 0.111111 \\
0 & 1 & 0.571429 & 0.428571 & 0.75 & 0.25 & 0 & 1 & 0 & 1 \\
0.28571429 & 0.71428571 & 0.285714 & 0.714286 & 0 & 1 & 1 & 0 & 0.444444 & 0.555556 \\
1 & 0 & 0.428571 & 0.571429 & 0.75 & 0.25 & 1 & 0 & 1 & 0 \\
0.28571429 & 0.71428571 & 0 & 1 & 0.75 & 0.25 & 1 & 0 & 0 & 1 \\
0.28571429 & 0.71428571 & 0.714286 & 0.285714 & 0.75 & 0.25 & 0 & 1 & 0.777778 & 0.222222 \\
\hline
\end{tabular}

Dari tabel 4 tersebut maka dilanjutkan untuk proses inferensi yang ditunjukkan pada tabel 5 . 
Tabel 5. Hasil inferensi

\begin{tabular}{cccccccccc}
\hline \multicolumn{2}{c}{$Z C 1$} & \multicolumn{2}{c}{$Z C 2$} & \multicolumn{2}{c}{$Z C 3$} & \multicolumn{2}{c}{$Z C 4$} & \multicolumn{2}{c}{$Z C 5$} \\
\hline rendah & tinggi & rendah & tinggi & rendah & tinggi & rendah & tinggi & rendah & tinggi \\
\hline 6 & 7 & 4 & 5 & 1.7143 & 2.286 & 0.8571 & 1.143 & 3.857 & 5.143 \\
6 & 7 & 4 & 5 & 1.7143 & 2.286 & 0.8571 & 1.143 & 3.857 & 5.143 \\
10 & 3 & 8 & 1 & 4 & 0 & 2 & 0 & 9 & 0 \\
8 & 5 & 6 & 3 & 2.8571 & 1.143 & 1.4286 & 0.571 & 6.429 & 2.571 \\
3 & 10 & 1 & 8 & 0 & 4 & 0 & 2 & 0 & 9 \\
8 & 5 & 6 & 3 & 2.8571 & 1.143 & 1.4286 & 0.571 & 6.429 & 2.571 \\
8 & 5 & 6 & 3 & 2.8571 & 1.143 & 1.4286 & 0.571 & 6.429 & 2.571 \\
\hline
\end{tabular}

Langkah akhir pemberian bobot nilai kriteria dengan menggunakan algoritma Fuzzy Tsukamoto adalah proses Deffuzzifikasi, yang hasilnya terdapat pada tabel 6.

Tabel 6. Hasil deffuzzifikasi

\begin{tabular}{ccccc}
\hline $\boldsymbol{C 1}$ & $\boldsymbol{C 2}$ & $\boldsymbol{C 3}$ & $\boldsymbol{C 4}$ & $\boldsymbol{C 5}$ \\
\hline 6.429 & 5.5 & 4.2857 & 2.762 & 1.714 \\
6.429 & 5.8 & 4 & 1.714 & 2.143 \\
3 & 5.90909 & 5 & 2.974 & 3 \\
5.857 & 5.28571 & 3.8571 & 2.143 & 1.143 \\
3 & 1 & 5 & 4.571 & 1 \\
5.857 & 3.57143 & 3 & 4.224 & 2.429 \\
5.857 & 6.57143 & 5.1429 & 2.926 & 2.429 \\
\hline
\end{tabular}

Dari hasil defuzzifikasi pada tabel 6, maka dapat dipergunakan sebagai atau mewakili nilai dari mahasiswa untuk dilakukan pembobotan menggunakan algoritma SAW, yang kemudian dapat dilanjutkan proses normalisasi berdasar formula (1), yang mana hasil normalisasi tersaji pada matrik gambar 4.

$$
x=\left[\begin{array}{ccccc}
0,467 & 0,182 & 0,833 & 0,604 & 0,583 \\
0,467 & 0,172 & 0,778 & 0,375 & 0,467 \\
1 & 0,169 & 0,972 & 0,651 & 0,333 \\
0,512 & 0,189 & 0,75 & 0,469 & 0,875 \\
1 & 1 & 0,972 & 1 & 1 \\
0,512 & 0,28 & 0,583 & 0,942 & 0,412 \\
0,512 & 0,152 & 1 & 0,64 & 0,412
\end{array}\right]
$$

\section{Gambar 4. Matriks normalisasi}

Berikutnya adalah menghitung nilai akhir preferensi (rangking) dari setiap judul berdasarkan formula (2) sebagai berikut :

$\mathrm{V} 1=(0,467 * 0,25)+(0,182 * 0,05)+(0,833 * 0,35)+(0,604 * 0,40)+(0,583 * 0.05)$ $\mathrm{V} 1=0.641$ 7.

Dengan cara yang sama dapat dihitung pula preferensi masing - masing judul yang tersaji pada tabel

Tabel 7. Nilai preferensi / rangking

\begin{tabular}{cc}
\hline Mhs & Preferensi \\
\hline 1. & 0.64159 \\
2. & 0.52418 \\
3. & 0.77563 \\
4. & 0.58004 \\
5. & 0.99028 \\
6. & 0.68523 \\
7. & 0.71106
\end{tabular}

Dari hasil nilai preferensi / rangking seperti yang tercantum pada tabel 7 di atas, maka dapat dilakukan penentuan manakah dari judul penelitian yang diajukan oleh mahasiswa yang akan disetujui dengan cara membandingkan masing masing nilai preferensi / rangking dengan nilai batas bawah preferensi / rangking yang telah ditentukan sebesar 0.6. Jika nilai preferensi / rangking kurang dari nilai batas bawah maka judul yang diajukan 
ditolak, sebaliknya judul yang diajukan akan diterima. Adapun contoh dari perbandingan nilai preferensi / rangking dengan nilai batas bawah terdapat pada tabel 8 .

Tabel 8. Perbandingan Nilai preferensi / rangking dengan batas bawah

\begin{tabular}{cccc}
\hline Mhs & Preferensi & Batas bawah & Hasil \\
\hline 1. & 0.64159 & 0.6 & Diterima \\
2. & 0.52418 & 0.6 & Ditolak \\
3. & 0.77563 & 0.6 & Diterima \\
4. & 0.58004 & 0.6 & Ditolak \\
5. & 0.99028 & 0.6 & Diterima \\
6. & 0.68523 & 0.6 & Diterima \\
7. & 0.71106 & 0.6 & Diterima \\
\hline
\end{tabular}

\subsection{Tampilan Program}

Adapun hasil tampilan program pada penelitian ini dijabarkan sebagai berikut :

1 Tampilan Menu utama

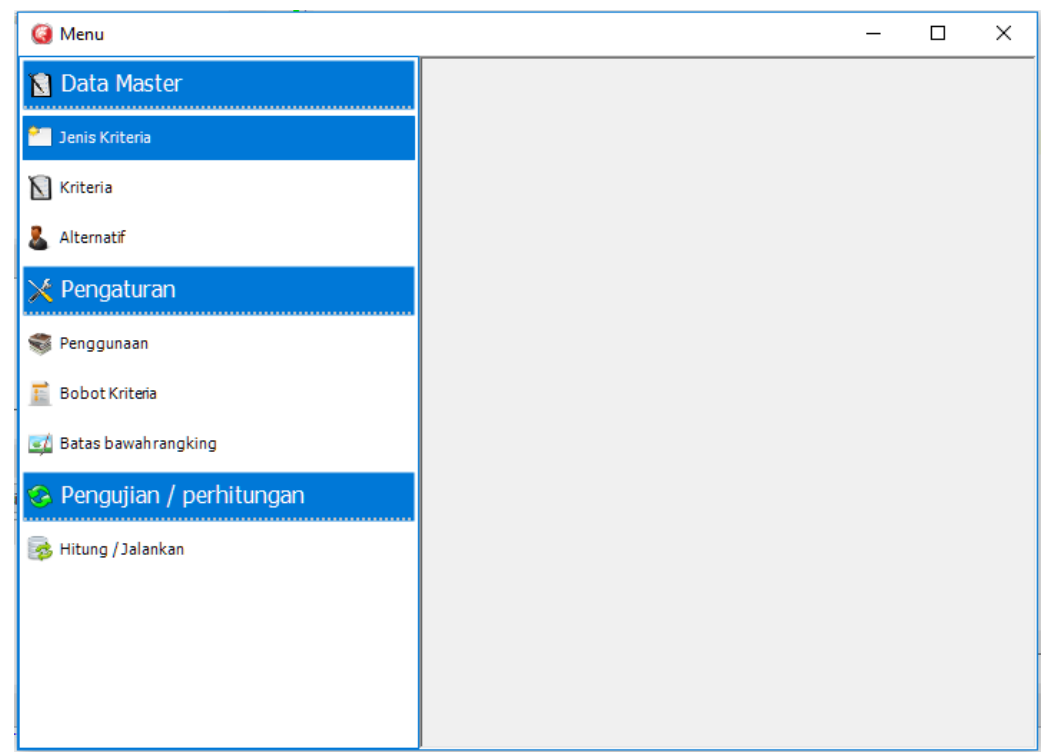

Gambar 4. Tampilan Form Menu Utama

Pada form menu utama ini berfungsi sebagai navigasi ke masing - masing form yang digunakan pada sistem pembobotan judul penelitian. Adapun beberapa menu yang terdapat pada sistem sebagai berikut :
a. Form jenis kriteria
b. Form Kriteria
c. Form Alternatif
d. Form Penggunaan
e. Form Bobot Kriteria
f. Form Batas Bawah Rangking
g. Form Hitung / Jalankan 
2 Tampilan form Jenis kriteria

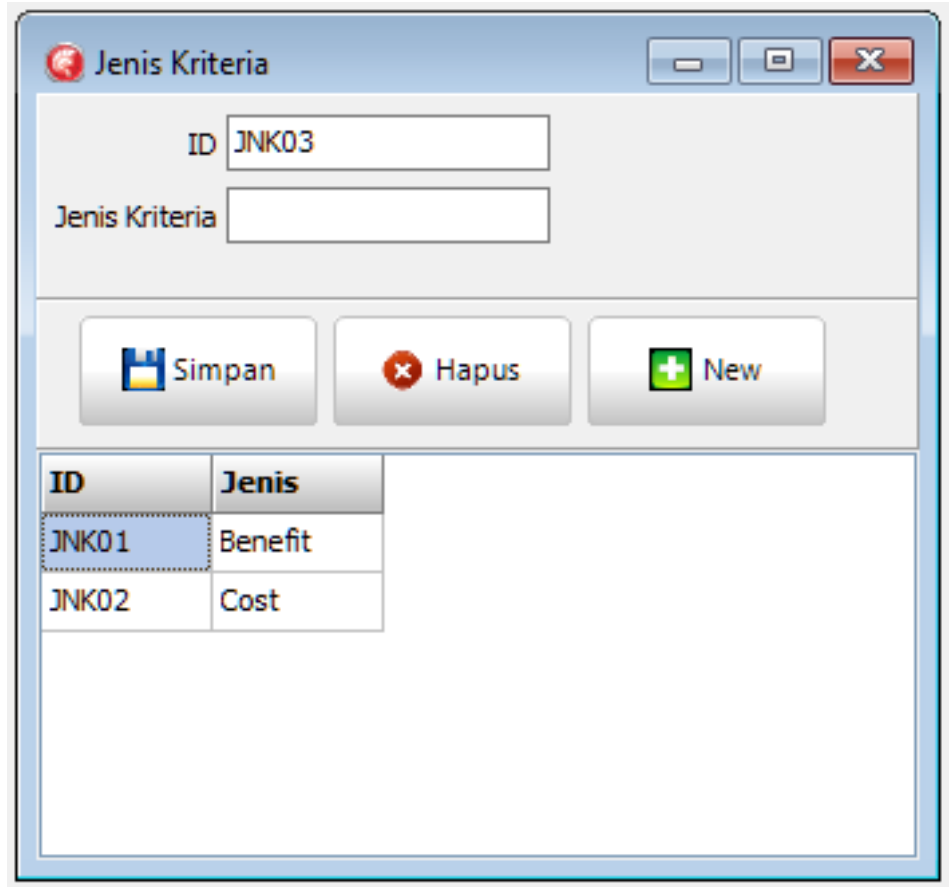

Gambar 5. Tampilan Form Jenis Kriteria

Pada form jenis kriteria ini digunakan untuk manajemen data jenis kriteria baik penambahan, perubahan dan menghapus data.

3 Tampilan Form Kriteria

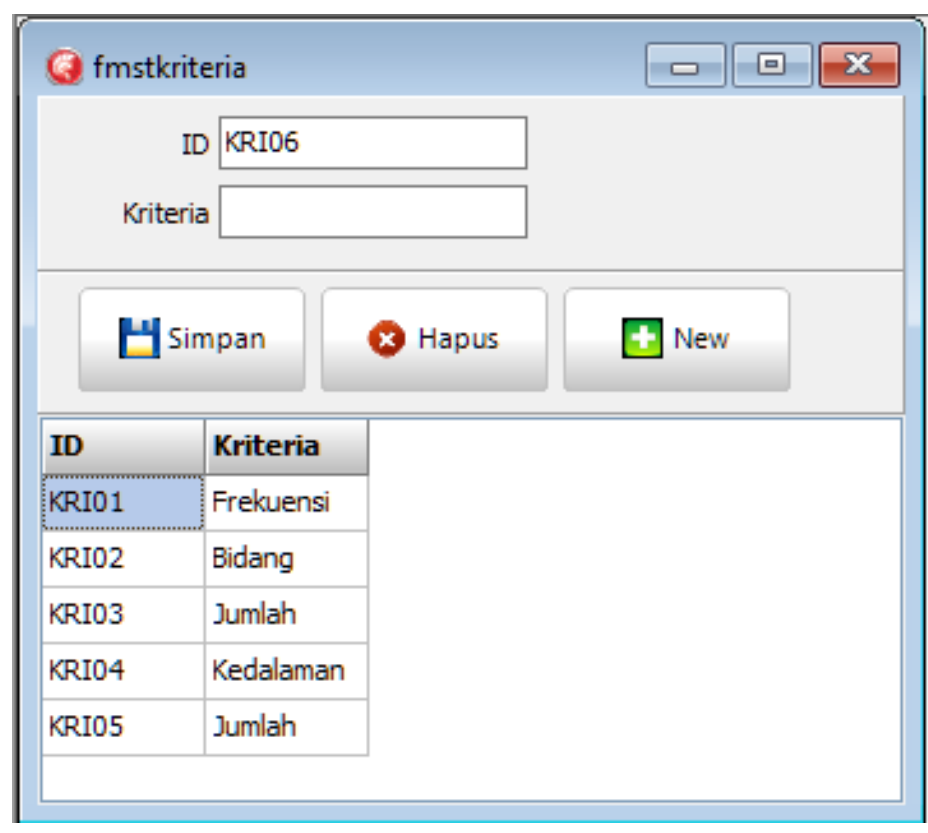

Gambar 6. Tampilan Form Kriteria

Pada form kriteria ini digunakan untuk manajemen data kriteria baik penambahan, perubahan dan menghapus data. 
4 Tampilan Form Alternatif

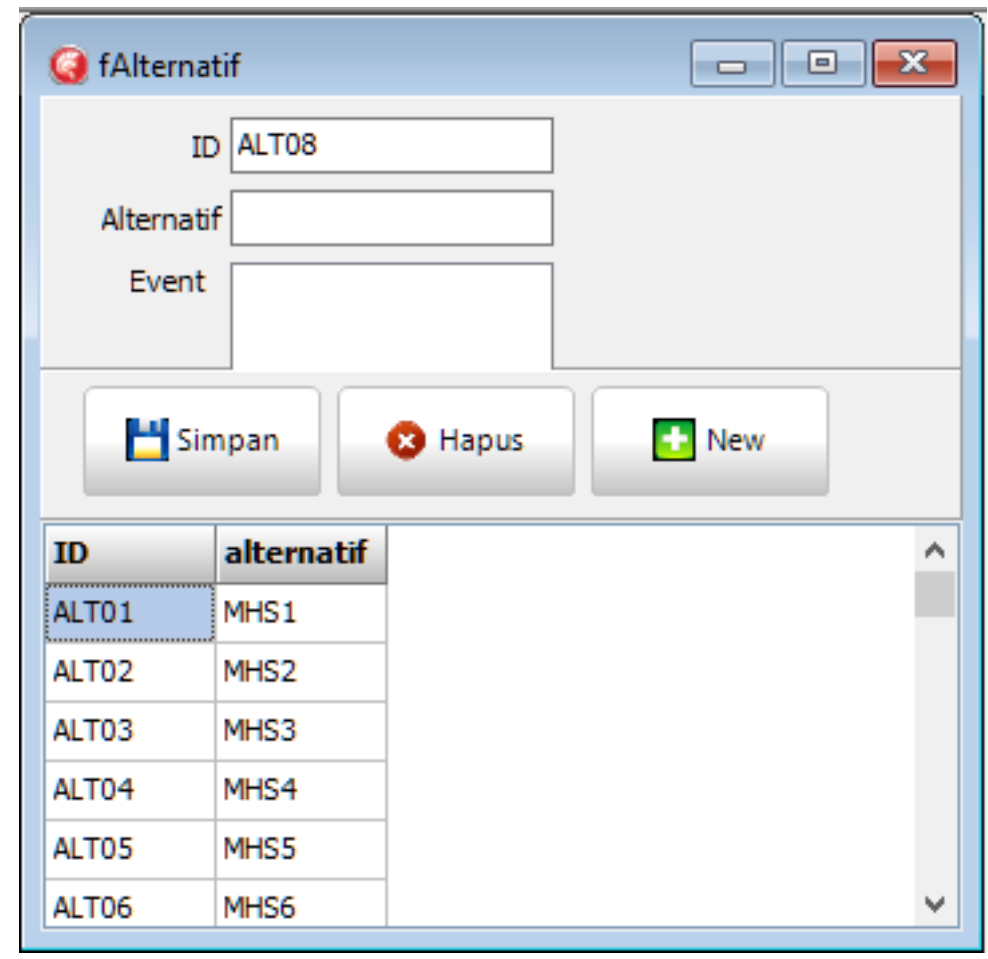

Gambar 7. Tampilan Form Kriteria

Pada form kriteria ini digunakan untuk manajemen data Alternatif yang akan dihitung rangkingnya, baik penambahan, perubahan dan menghapus data kriteria.

5 Tampilan Form Penggunaan

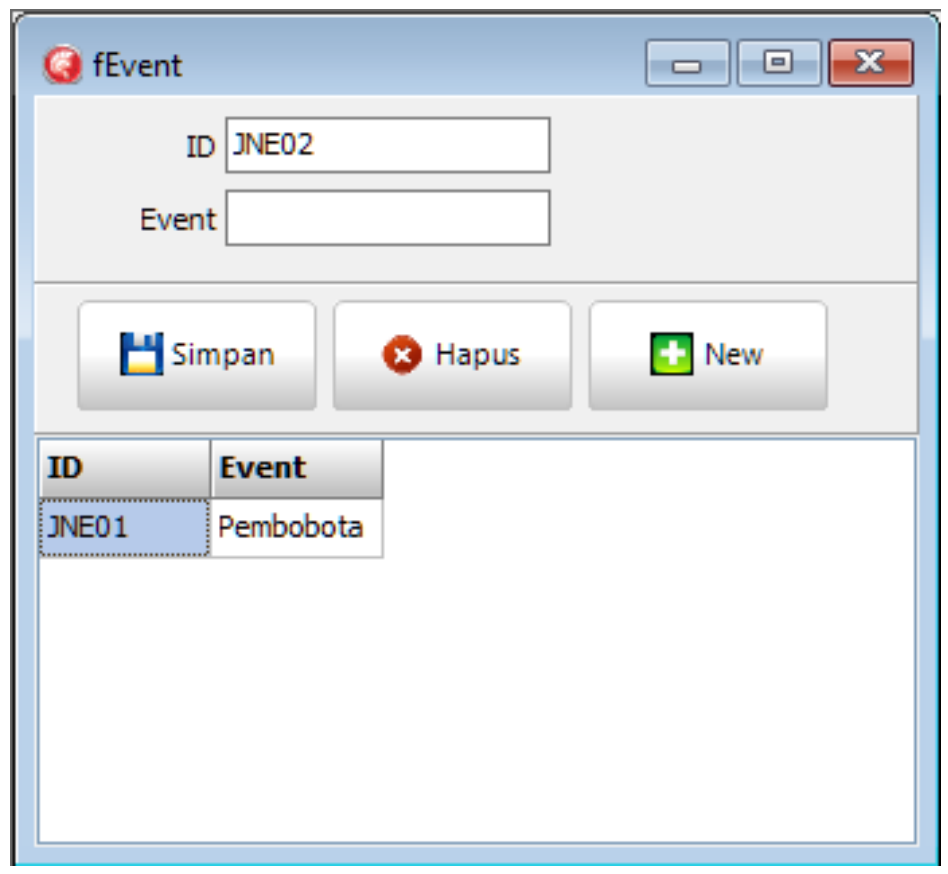

Gambar 8. Tampilan Form Even / Penggunaan

Pada form kriteria ini digunakan untuk manajemen data Even atau penggunaan pembobotan, baik penambahan, perubahan dan menghapus data even. 
6 Tampilan Form Bobot Kriteria

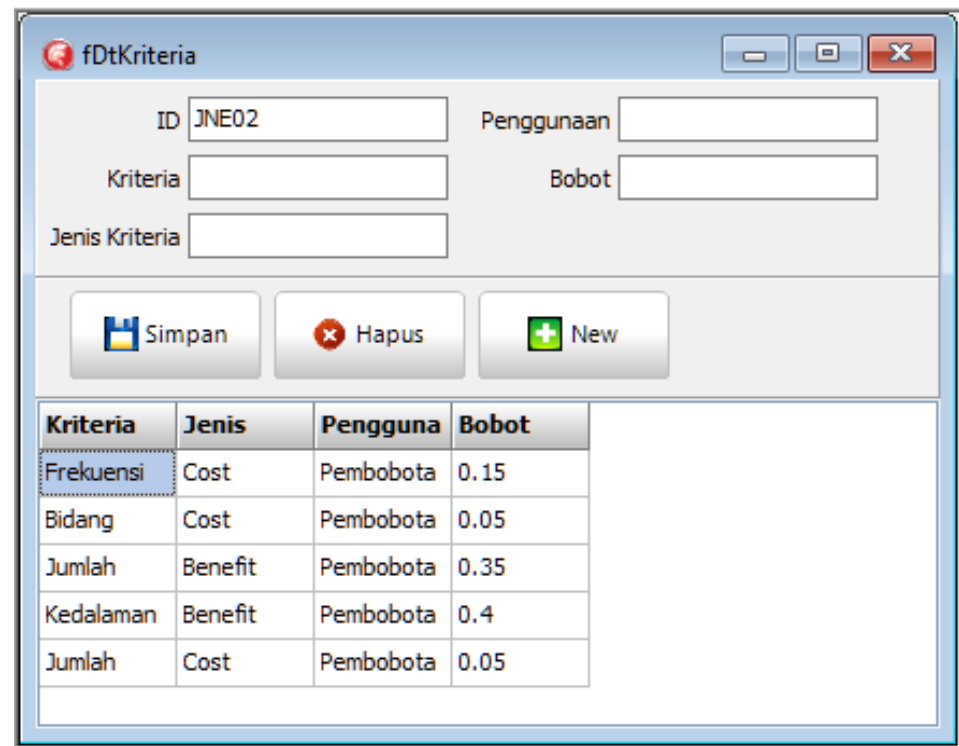

Gambar 9. Tampilan Form Pembobotan Kriteria

Pada form ini digunakan untuk manajemen bobot atau mengatur bobot masing - masing kriteria yang diberikan.

7 Tampilan Form Hitung / Jalankan

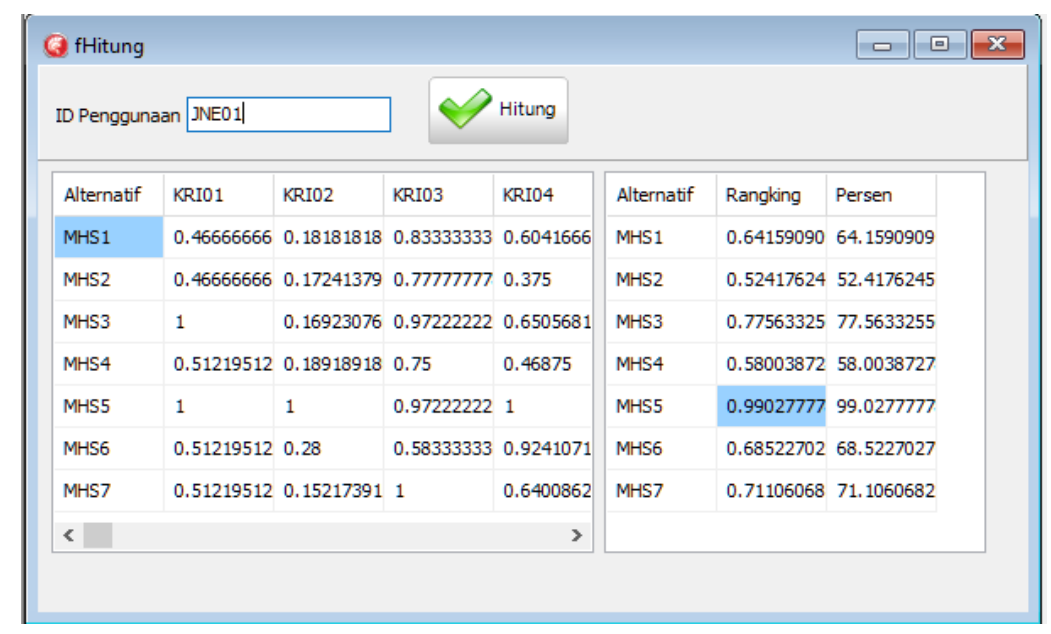

\section{Gambar 10. Tampilan Form Hitung/Jalankan}

Pada form ini digunakan untuk melakukan proses perhitungan pembobotan dan rangking menggunakan kombinasi lagoritma SAW dan Fuzzy Tsukamoto. Pada gambar 11 tersebut menunjukan dua tabel, dimana tabel sebelah kiri menunjukkan hasil normalisasi, sedangkan pada tabel sebelah kanan menunjukkan hasil perhitungan rangking dan bobot dalam persen.

\section{KESIMPULAN}

Dari peneitian yang telah dilakukan tersebut maka dapat diambil kesimpulan bahwa :

1) Sistem approval-system proposal skripsi mahasiswa ini dirancang dengan menggunakan kombinasi algoritma SAW dan Fuzzy Tsukamoto sebagai perhitungan bobot atau rangking judul penelitian, dimana kombinasi dari dua algoritma ini telah dibandingkan pada penelitian sebelumnya, dan dinyatakan lebih presisi daripada hanya menggunakan algoritma SAW saja.

2) Penerapan kombinasi algoritma Fuzzy Tsukamoto dan SAW pada sistem pembobotan judul penelitian mahasiswa ini dapat dilakukan dengan menggunakan database $M y S Q L$ serta 
menggunakan IDE Embarcadero Delphi XE7. Adapun dalam menggambarkan fungsionalitas yang diharapkan dari sebuah sistem menggunakan Diagram Use Case.

Selain dari kesimpulan yang didapat pada penelitian ini juga masih memiliki bebrapa kelemahan, diantaranya adalah pemberian kriteria dan bobot masing - masing kriteria yang masih bersifat subjektif. Sehingga masih sangat diperlukan beberapa kritik atau saran yang bersifat membangun demi kebaruan penelitian dan pengembangan yang lebih baik.

Pada penelitian berikutnya mungkin dapat dikembangkan dengan membandingkan kombinasi dari beberapa algoritma fuzzy lain. Selain itu pada penelitian ini masih dikembangkan menggunakan platform desktop berbasis Microsoft Windows, ada baiknya jika pada penelitian mendatang dapat dikembangkan dalam bentuk mobile.

\section{UCAPAN TERIMA KASIH}

Atas tercapainya hasil penelitian ini, tidak lupa peneliti sampaikan ucapan terima kasih kepada beberapa pihak yang telah terlibat dan mendukung atas keberhasilan penelitian ini. Ucapan ini peneliti sampaikan kepada LPPM Universitas Nusantara PGRI Kediri yang telah membantu mendanai melalui hibah bantuan stimulus penelitian tahun akademik 2016/2017 dengan Nomor Surat Keputusan 0378.01/UNP-Kd/A/IV/2017..

\section{DAFTAR PUSTAKA}

[1] A. Ristyawan, "Penggunaan Fuzzy Tsukamoto Pada Algoritma Saw Dalam Kasus Pembobotan Judul Proposal Mahasiswa Pada Universitas ABC," in Penggunaan Fuzzy Tsukamoto Pada Algoritma SAW Dalam Kasus Pembobotan Judul Proposal Mahasiswa Pada Universitas ABC, 2017, pp. 115-120.

[2] E. Prasetyo, Data Mining : Mengolah data menjadi informasi menggunakan MATLAB. Yogyakarta: Penerbit Andi, 2014.

[3] E. Turban, Jay E. Aronson, and Ting-Peng Liang, Decision Support Systems and Intelligent Systems (7th Edition), 7th ed. New Delhi: Prentice-Hall, 2007.

[4] J. R. Jang, C.-T. Sun, and E. Mizutani, Neuro-Fuzzy and Soft Computing. Upper Saddle River: Prentice-Hall, 1997.

[5] W. Kaswidjanti, A. S. Aribowo, and C. B. Wicaksono, "Implementasi Fuzzy Inference System Metode Tsukamoto Pada Pengambilan Keputusan Pemberian Kredit Pemilikan Rumah," in Telematika, 2014, vol. 10, pp. $137-146$.

[6] T. Murti, L. A. Abdillah, and M. Sobri, "Sistem Penunjang Keputusan Kelayakan Pemberian Pinjaman Dengan Metode Fuzzy Tsukamoto," in Seminar Nasional Inovasi dan Tren (SNIT)2015, 2015, pp. 252-256.

[7] A. Kadir, Tuntunan Praktis: Belajar Database Menggunakan MYSQL. Yogyakarta: Andi Publisher, 2008.

[8] Sugiyono, Metode Penelitian Kuantitatif Kualitatif dan R\&D. Bandung: Alfabeta, 2012.

[9] Sholiq, Pemodelan Sistem Informasi Berorientasi Objek Dengan UML. Yogyakarta: Graha Ilmu, 2006. 